\title{
TWO WAYS OF CONCEIVING TIME IN SPORTS
}

\author{
Irena Martínková, Jim Parry
}

Faculty of Physical Education and Sport, Charles University, Prague, Czech Republic

Submitted in September, 2010

BACKGROUND: This paper explores a foundational concept for our understanding of sport - the concept of time. OBJECTIVE: The objective of this paper is to explain two different concepts of time in sport.

METHODS: Our methodology is philosophical, involving both conceptual and phenomenological analysis and the application of the outcomes to sports practice.

RESULTS: First, two concepts of time and their role in sport are discussed - time as linear, measurable, homogeneous and objective; and time as discussed in the philosophy of existence, namely in the work of Martin Heidegger, in which he introduces the concept of "original temporality". Second, sports are classified into four different groups depending on the role of time in them, and basic characterisations of each are worked out. While within the first three groups the concept of objective time is salient, a suggestion is made regarding the potential of the fourth group, which includes high risk sports, for the realisation of original temporality.

CONCLUSIONS: The two concepts of time presented in this paper explain the basis of sport and show its relationship to the human experiencing of sport activities. The text shows that the concept of objective time is necessary for the practice of some sports, whilst other sports use it rather in a secondary way, e.g. for the comparison of winners. Original temporality as a basis of human experiencing is present in all sports. While in most of them it is limited by objective time, in some sports (especially in high risk sports) the possibility of the realization of original temporality is opened.

Keywords: Time, sport, regulation, experiencing, Heidegger, original temporality.

\section{INTRODUCTION}

In an earlier paper, Martínková (2007) showed the difference in the conceptions of time in the practice of Western sports compared with the practice of martial paths in a Zen way. In this paper we aim to show the difference in the conceptions of time in the practice of Western sports compared with the conception of time as discussed in the philosophy of existence, with special reference to the early work of Martin Heidegger. The Western sports conception describes time as being linear, objective, homogeneous and measurable, and this conception of "objective time" constitutes and regulates the practice of most existing sports. In the conception of time as discussed in the philosophy of existence, however, we shall need to understand the idea of the "original temporality" of being of the athlete, which comes to the fore. We shall show how this conception of time is connected, in the work of Martin Heidegger, to the very Being (Existenz) of humans; and how the two conceptions of time are related in the area of sport.

As part of our enquiry, we shall categorize sports into four groups according to the role of time in them: time constituted sports, event sports, mixed sports (i.e. sports with both time- and event related elements), and sports encouraging the experiencing of original temporality.
We shall describe the role of time within each group and for each group we shall give examples of how the notion of time in them affects human existence. While in the first three groups the concept of time as linear, measurable, homogeneous and objective plays a very important role, the fourth group is not limited by this notion of time to such an extent, and as such is able to manifest human original temporality.

\section{Two concepts of time}

Usually, when we talk about time, we understand it as linear, homogeneous, infinite, objective, divisible, quantifiable and measurable. We shall call this notion of time "objective time". This understanding of time is characterized by an axis, which is divided into past, present and future, where the present is a point between the past and the future. The length of this axis can be divided into a myriad of moments or units of the same duration, each following successively. Time conceived as such refers back to Aristotle and was further developed with the rise of science (cp. Heidegger, 1987, $30 \mathrm{f}$;; Heidegger, 1997, § 19a). While this concept of time has been overcome with the arrival of the theory of relativity, as well as challenged by certain philosophers (e.g. Augustine, Bergson, Husserl and Heidegger), it remains unchanged in our everyday thinking, as it forms a steady 
and indispensable basis for contemporary Western society (cp. Sokol, 2004, p. 123). There follow some examples.

The possibility of dividing and measuring time influences the everyday life of people in quite specific ways. The axis of time is divided into various units (years, months, weeks, etc.) and people use different devices (watches, diaries) to know where they are in the commonly understood time. This understanding of time enables a specific time location for various activities, which can start and finish at an exact time, so that everybody knows when to be where and how much time they can expect to spend there. This possibility breaks human life into different periods that are to be respected, and permits the development of the idea of the management of time, which is so important for Western society. Certain activities, such as work, school lessons and leisure activities begin and end at a certain time (on a daily or a weekly or a monthly level), sometimes independently of what we wish or need. In this way, human life becomes more or less time-structured, on the basis of a commonly understood objective time.

Objective time is also part of the contemporary general emphasis on high performance. Time is said to be precious - "time is money" - and thus it should not be wasted. In this way of thinking, it is mainly the result of our performance that is important, while the process of the activity itself is usually considered less valuable (Hogenová, 1997, p. 47). As such it tends to be underestimated and shortened as much as possible. This leads to a hectic pace, with a hastening toward and impatience for the result, which then disenables the process of the development of proficiency and the full maturation of the individual, thus risking a lower quality of any outcome.

Similarly, human beings are subject to objective time on the basis of counting the years of their lives, i. e. their age. This is very apparent in our society, in which no matter how mature the human being is (unless they are excepted based on some ground, e.g. mental illness), they are supposed to enter specific activities at specific times. For example, there is a given span of age when one can enter kindergarten, school education, the army, commencing certain sports, etc.

The infiniteness and objectivity of this notion of time lead the human being into thinking that the axis of time is infinite and that there is plenty of time to come and to be enjoyed. Especially in youth, it seems that life is almost endless, with death being a point in the faraway future - and as such life is taken for granted. This approach also affects the quality of one's life, since it looks as though there is lots of time to come, so that the human being does not have to make choices and tends to postpone opportunities for later. And often, attitudes that one learns in youth persist throughout one's entire life.
While most of us may think of this notion of time as unproblematic (or maybe even the only one), there are some very different views on the matter. One such view arises especially when we start asking how this notion of objective time arose, as did Martin Heidegger in his work Being and Time (Sein und Zeit), with his analyses of the way of being of the human (or Dasein - i. e. "being there").

Dasein is one's own Being (whose being is "always mine"). It is distinguished from other kinds of being as one whose very being is an issue for it - compared to life (the being of plants and animals), readiness to hand (the being of tools or equipment), and presence at hand (the being of objects). This kind of self concern as Care (Sorge) is part of the very character of Dasein. And Care grows from Dasein's “original temporality”, which we must now explain.

According to Heidegger, original temporality (Zeitlichkeit) is not an axis, on the basis of which we can identify the past, the present and the future, and which is a sum of successive moments that have no content, as is seen with the concept of linear time (Zeit). Rather, it is a unity of three moments, or "ecstases" (Ekstasen): Dasein's past (the "having been", or Gewesenheit) and its projection into the future (Zukunft) which together yield the present (Gegenwart). Dasein is not static, but is rather an entity that continually makes and re-makes (temporalizes) itself in the dynamic unity of these three "ecstases". According to Heidegger: "Temporality temporalizes itself as a future which makes the present in the process of having-been" (Zeitlichkeit zeitigt sich als gewesende-gegenwärtigende Zukunft) (Heidegger, 1967, p. 350). He presents Dasein's temporality as being stretched out and stretching itself out (das erstreckten sich erstrecken) (Heidegger, 1967, p. 375), coming out of itself into the world.

The modes of the temporalizing of the three ecstases may differ, offering thus different "ways of being", of Dasein. Heidegger highlights one way of existence as an authentic existence, in which it is the authentic future that has a priority in the ecstatical unity. In this context, the understanding of human mortality is important. The authentic future is finite, and only on the basis of this understanding of its mortality can Dasein project itself authentically. Without this realization Dasein cannot be authentic and whole. The idea of mortality, however, does not simply mean that death is to come at some time in the far future, but rather that Dasein's existence is fundamentally mortal - as Heidegger says, human existence is "being towards death" (Sein zum Tode): "Death is a way to be, which Dasein takes over as soon as it is" (Heidegger, 1967, p. 245). In this way, death

\footnotetext{
${ }^{1}$ In this text, to enable easier orientation within Heidegger's book Being and time, we refer to it by the pagination of the original work Sein und Zeit (it is printed on the side of the translated English text).
} 
cannot be seen in its relation of duality to life (life or death, life and death), but rather it is a phenomenon of life (death in life, mortal life) (Heidegger, 1967, § 49). (cp. Heidegger, 1967, § 47 f., § 65)

However, Dasein most often does not understand its own being in this way, since there is an easy tendency to overlook one's own being while attending to and being absorbed by things in the "world". The world then seems to Dasein as being the sum of things in it, including itself as a thing. Within this tendency, the existence of Dasein takes on the form of "falling" (Verfallen), which is not to be understood as a negative evaluation of Dasein, but simply a description of the way of being of a Dasein that is absorbed with things in the world. This is inauthentic being, when Dasein temporalises from this present, rather than the future, such that the tendency of falling predominates (Heidegger, 1967, § 38, § 65). In thus understanding itself, Dasein does not yet realize its difference from other things in the world - for one thing, that Dasein is "being in the world" (In-der-Welt-sein), i.e. that the world is opened and understood only through Dasein's own temporalizing, and that Dasein is defined by the fact that, in its Being, this very Being is an issue.

Now, what is the relationship between objective measurable time and the temporality of Dasein? Heidegger explains that this notion of objective measurable time actually derives from the "original" temporality of the way of being of Dasein, and shows (1967, § $79 \mathrm{ff}$.) the steps in its development, briefly described as follows: "If temporality makes up the primordial meaning of Dasein's Being, and if moreover this entity is one for which, in its Being, this very Being is an issue, then Care must use "time" and therefore must reckon with "time". 'Time reckoning' is developed by Dasein's temporality. The "time" which is experienced in such reckoning is that phenomenal aspect of temporality which is closest to us. Out of it arises the ordinary everyday understanding of time. And this understanding evolves into the traditional conception of time" (Heidegger, 1967, p. 235).

Thus, from the original temporality of Dasein, Heidegger identifies several steps towards the development of the notion of objective, measurable time. One of these, for example, he calls "datability" (Datierbarkeit), which is one of our common ways of reckoning with time, in which the "now" is seen as as "now that ...", which means connected with an activity, an intention. It points to some content - for example something that has to be done now: "now that I must go to the library" (cp. Heidegger, 1967, § 79; 1997, § 19b). And this kind of everyday counting by moments to be filled is a step towards the abstraction that is objective time, in which every successive moment is homogeneous and content free ("empty").

Understanding time as objective and measurable is related to inauthentic existence, in which Dasein does not understand the self as being temporality, but rather as a thing that exists in objective time.

\section{Time in sport}

In the following sections, we shall present both above mentioned notions of time with respect to sport. By sport we mean "rule governed competitions wherein physical abilities are contested" (Parry, 1998, p. 205); they are more formal, serious, competitive, organised, and institutionalised than the games and practical activities from which they often sprang. In this text, we shall be referring mainly to the role of time in high-level sport, in which the role of time is seen much more obviously than, for example, in recreational sport, in which time may be taken less precisely. Nevertheless, this is not to deny the importance of time in recreational sport as well.

How is time present in sport? Obviously, if Heidegger's understanding of original temporality is a fundamental mode of being of Dasein, that notion of time is present in any human activity, in the practicing of any kind of sport. But, just as in most other human activities in our society, the notion of objective time is also present in sport. Thus, in sports, both above mentioned notions of time meet. In the following we shall show in what ways the objective form of time is present in sport, and how it affects the original temporality of Dasein.

On the most general level, sports coincide with the management of time within Western society. The schedules of sport stadia are firmly set, with start times of the practice sessions, league games and tournaments known well in advance, so that everyone knows where and when to be, as if a human being is always ready to perform. The participants are supposed to come on time, no matter how they feel or what they might like to be doing at the scheduled moment

At the level of practice, children work hard from as early an age as possible so that they can develop as quickly as possible. Furthermore, people who compete in sport are put into groups according to their age, no matter how mature they are. This can involve enormous differences, especially in younger athletes, where the categories can change every year or two years according to the age of the participant. The differences here can be vast and may discourage from sport participation those participants who mature at a slower pace, as they are not able to compare with their peers.

Since time is counted as precious and it is important to perform as well as possible to show one's worth, athletes are supposed not to waste any time, and to practice as often and as much as possible. This often leads to over training and injuries, and possibly also to their dropping out of sports participation. It can also lead to the use of performance enhancing substances, as some are supposed to shorten the time needed for recovery 
between practice sessions or after sustaining an injury. Such an approach has vast consequences on the way in which the athlete experiences sports. It does not leave much space for individual maturation, rhythm, pace and preferences, which are all rather constrained.

But time plays yet another role within sport, which touches the very formation of sport. The role of time, conceived as objective, is constitutive and regulative within sports. In certain sports it is both, whilst some sports show it in only one of these functions. And even though the exactness of time-measurement may differ when used at different levels of sport (e.g. professional, recreational and school sport) as well as in different kinds of sports, the objective notion of time is more or less important for all of them. We shall now show the importance of the objective notion of time for sport, together with its various modes of employment. We shall also show how original temporality (based on Heidegger's philosophy) manifests itself in sport practice.

We shall distinguish four groups of sports according to the role played by time in them. These four groups are partly based on Kretchmar's (2005) division of games into time regulated and event activities, with some necessary modification for our purposes. Since Kretchmar's description of games flaws is partly related to time, his analyses are a suitable basis for ours. But we have different aims: while Kretchmar uses this distinction to describe the flaws in games, we seek to describe the role of time in sports. And this difference in aims demands two modifications. Firstly, we introduce two more groups of sports, which is necessary to show the notion of time in sport more fully. Secondly, we change the names of his groups in order to show the role of time in them more precisely, because we highlight the constitutive function of time in the first group of sports, while the regulative function is only secondary. (These two functions of time relate to the notions of constitutive and regulative rules - see D'Agostino, 1981). Furthermore, the regulative function of time can be found in other groups of sports (e.g. event sports), so it is not the main characteristic of our first group.

The four groups that we identified for the purpose of exploring the topic of time in sport are the following:

- Time constituted sports,

- Event sports,

- Mixed sports (sports with both time- and event related elements),

- Sports encouraging the experiencing of original temporality.

Out of these four groups, the first three have a close relationship to the notion of time as objective. Within the fourth group we shall discuss sports that encourage the manifestation of original temporality. We shall now consider these four groups in terms of their differing and specific time related characteristics.

\section{Time constituted sports}

Time constituted sports are those in which time limits the span of the sport performance. The game/contest is started and finished at a certain moment, and it is the time limit which determines the final score. Often the time-span is divided into certain periods (halves, quarters), which may be interrupted by time outs, and increased by added injury time. The time span may be determined by "game time" or by "playing time". Game time is the measure when continuous running time is used (as in football); playing time is the measure of intermittent time when, for example, a stop clock is used for measuring the elapsed time of the game, such as the periods when the ball is in play (as in basketball). It is possible to combine the two, as used to be the case in floorball, which was played for 3 periods of 20 minutes of continuous time, with stop clock intermittent measurement of the final 3 minutes.

We usually count team sports, such as basketball, soccer and ice hockey, as being in the group of time constituted sports, but it also includes individual sports, such as martial sports (often wrongly referred to as "martial arts", see the differentiation in Martínková \& Vágner, 2010). For example, in the case of combat performances (kumite) in sport karate a match usually lasts 3 or 5 minutes. However, there is also another way of contesting within martial sports, as seen in the performance of forms (kata), which belongs among event sports (see later). Time in time constituted sports is a result forming factor, and the time restriction is supposed to enable competition and make the game more challenging and exciting, because there is a huge difference between performing under time pressure and performing without having to take into account the time on the game clock. Thus, in time constituted sports, the participant is put under pressure by means of a certain requirement which makes their performance more demanding. Apart from the impact of time-restriction on the quality of the performance, an agreed to and understood time limit makes it possible to compare performances/games to each other (e.g. in a soccer league, the sums of all final results are compared to determine the winner in the league, and the "most valuable" player of an American football match or tournament is determined on the basis of achievements measured within that time - gaining the most yards, or scoring the most touchdowns).

There is also thought to be a practical advantage to time constituted sports in terms of the time management of the audience (i.e. people know how much time they will spend at the stadium) as well as for television programming (cp. Kretchmar, 2005, p. 39) - although intermittent time measurements complicate the picture a little.

In time constituted sports the limit on the duration of the game is not usually the only time limitation there is. One of the problems of time constituted sports is 
that, although the set period of time allows for contesting, it does not require it. This can lead to slow down tactics and a reduction of the potential of the game, which Kretchmar (2005) sees as a flaw of time constituted sport games. For this reason most time constituted sports employ anti stalling regulations to allow the referee to regulate the game so that one team cannot so easily "eat up" the clock, whilst avoiding the contest. A good example of this approach can be seen in basketball, which is a highly time regulated sport. For example, the "shot clock" or " 5 seconds rule" influence the nature of the game, as they force the team with the ball to play positively and shoot, rather than to employ delaying tactics. Thus time has two different roles in these sports - it constitutes them as well as regulates them.

How does time in time-constituted sports affect human existence? Objective time demands that the game be played no matter how the athlete feels or whether he or she wishes to play, which can lead to a disrespecting of the self ("it is time to play the game" versus "I feel like playing the game"). Also, during the game, no matter how much one is enjoying the actual play or how dreadfully one feels during the game, one is supposed to play the game right through to the final whistle, buzzer or gun, and then no longer. Objective time dictates to human beings what to do, while they remain unaware that it is they who actually enable objective time its being. On the other hand, of course, without the notion of objective time there would be no sport of this kind (i. e. no "time constituted" sport)!

As soon as an athlete agrees to play the game and takes the urgency of the time limit seriously, he or she has to accomplish certain tasks within given time limits. This pressure of time on the performance of some activity makes it so urgent that the athlete is not usually aware of his or her own self, but rather is captured by having to deal with entities in the world (ball, opponents, goal, etc.). In Heidegger's terminology, the athlete remains in the tendency of falling (Verfallen) rather than seeing through it and understanding his/her own way of being.

Time limitation can also influence the pace and rhythm of human performance, because when time considerations add pressure to the performance, it is hard to keep to one's individual pace. However, this aspect of time-constituted sports may be understood as a challenge for the human being. To keep one's performance balanced no matter what stresses may be imposed can be seen as a worthwhile attitude to learn, both for better performance within the game and for life outside of the game.

Also, the time limitation that is a constituent aspect of these sports may remind the human being of the time limitation of human life itself. Just as in life, within a certain sport game the human being gets a limited span of time to do something in - in the case of a game, to contribute to a victory or a loss; in the case of life, to learn about who we are, or to allow ourselves to become lost in our everyday dealings. However, this notion of time is often understood as the time axis, in which the end of an activity is to come at some time in the distant future. What we often fail to realize in this context, in respect to human existence, is that the limitation (the end of the game, death) does not come after a certain time, but is always a part of one's existence, and concerns its very temporalizing (as described above). Every moment of one's existence is finite and unrepeatable.

\section{Event sports}

Event sports are those sports in which a certain task or, alternatively, a specified number of tasks, has to be completed (Kretchmar, 2005, p. 38). These sports originated as tests (which simply set one's abilities against a task) and were later developed into con-tests (requiring an opponent - see Kretchmar, 1988). The result of any test is decided simply according to whether or not one passes it. But contests are social activities, such as competitive sports, in which it is the comparison between the competitors' performances that decides the result.

Here, as distinct from time constituted sports, there is no specific time span to determine the winner. However, it cannot be said that time is completely absent in these sports. As time has different functions in different sports within this group, we have divided event sports into three groups:

- sports with the possibility of time measurement of the event,

- sports with the necessity of time measurement of the event,

- sports without the possibility of time measurement of the event.

\section{Event sports with the possibility of time measurement}

Event sports are based on comparisons between opponents. The clearest examples of sports with the possibility of time measurement are races, for example running and swimming competitions. Time measurement is just a possibility here, since using time as a basis for comparing opponents is not absolutely necessary. For example, in ancient Greek athletics, times were not measured and the winner was distinguished simply on the basis of immediate comparison within the single event. Guttmann (2004, p. 49) comments on this in the following way: "Why don't we know how fast the runner ran? We are tempted to respond that the Greeks lacked accurate chronometers. This may be the correct answer, but I suspect that it may have been the other way round - the Greeks had no accurate chronometers because they didn't care how fast the runner ran."

However, whilst not absolutely necessary, timings have become a popular way of comparing performances. Decisions on victories and places may demand very precise measurement as well as the help of other 
devices (e.g. cameras) to be able to show the differences between competitors. But, whereas different sports demand a different level of precision in time measurement for determining results, a certain level of accuracy has become necessary in all event sports because results (especially in modern times, and especially as "records") are supposed to be comparable across time and space (Parry, 2006).

Nowadays, in event sports with the possibility of time measurement, time is of great importance. It seems that it does not suffice to compare athletes within a single race, but new victors are compared with previous victors in the given event across time and space. Thus we have Olympic records, world records, national records or even school records that are kept to be compared with new performances, and which determine their worth.

Some of the sports use an increasingly refined measure of time; and sprint disciplines especially are among the most precisely timed. This measurement necessarily depends upon seeing time as objective, so that records are comparable. However, even using the most accurate devices does not mean absolute comparability. Exact comparability concerns not only the exactness of chronometers but also the comparability of all sport equipment as well as the external conditions (e.g. the influence of the wind), which must also be taken into account/under consideration. When trying to achieve an exactness of comparability, the measuring of sport results can become very complicated.

In this context we can remark that sport has actually influenced the development of measuring devices. Guttmann (2004, p. 48) talks of the stopwatch, which was invented around 1730 as an instrument to time races, as a symbol of the development of modern sports. During the centuries of development of time measurement, the measuring devices have become increasingly refined to the extent that time can be measured in an atomic second, though only a short time ago no one was bothered if a clock had a deviation of ten minutes during a day (Hempel, 2001, p.56 ff.).

\section{Event sports with the necessity of time measurement}

So, we have seen that there are occasions when time measurement may help greatly in determining the winner, for example when the difference between performances is very small. However, we might even suggest that there is a group of sports (or events) for which time measurement seems absolutely necessary, because they require the comparison of the performances of athletes who do not start a competition at the same time or place. This group includes, for example, downhill skiing (which calls for the refined measurement of successive performances), various disciplines of cross country skiing (in which competitors depart at set intervals and are separately timed), and athletics heats that select some "fastest losers" to go forward to the next round. It is dif- ficult to see how the required discrimination between successive performances could be achieved without accurate timings.

\section{Event sports without the possibility of time measurement}

In terms of this third group of event sports, it is not time that is measured and which decides the winner, but something else (e.g. distance in the shot-put, or points in volleyball). However, time can still be found here, too, since the duration of the game is often related to the number of actions that constitute a game. Sometimes, time has the function of regulating the performance of the event (e.g. the athlete must carry out the event within a certain span of time, otherwise he or she misses the attempt). However, the time regulation in this context is not meant to put the athlete under stress as it is in time constituted sports, but rather to enable him or her sufficient time for performing as well as enabling time planning for the sport competition. Events thus serve as a surrogate for temporal duration (Kretchmar, 2005, p. 47). This is nicely seen in the example of volleyball, in which not long ago tie-breaks could drag on for a long period of time and therefore made the duration of the game unpredictable. This caused problems in televising events, and so the game has recently been regulated by a limit of exchanges. Similarly, golf, which is an event sport, has penalties for slow play, and baseball can sometimes become time constituted at the demand of time management in the given society. For example, in Japan baseball is time regulated so that people can get home before the trains stop at midnight.

\section{Event sports - summary and discussion}

Our mania for measurement (whether it is time, distance, scores, etc.) is not without influence on our lives. In the context of measurement, Guttmann (2004, p. 51) says that, at the present time, we human beings have become what could be referred to as Homo mensor. The problem with event sports is that, with the measurement of outcomes, the entire performance of the human being is reduced to a number, and this number is dealt with as an object that is considered precious. Human beings then become victims of this approach, as they are pushed to perform ever better to out perform their opponents - they are haunted by time (distance, score, etc.). It is objective time that directs existence, rather than existence developing from within itself. Thus the richness of human performance as a whole (for example, fair-play, one's approach to practice or towards one's opponents, joyful striving, etc.) recedes into the background, whilst the number assumes overall importance. Along with this, what is also suppressed is the finding out of who we are. In Heidegger's terms, our original temporality is hidden to us, while we think we are an object among others. 
We can find the characteristics described for the time constituted group of sport to be present in this group of sports too, but, in fact, in an even more urgent form. Unlike in the previous group, the pressure of time comparisons within the given sport discipline forces the human being to perform ever more efficiently, pushing human beings to aim at their limits, without respecting their individual pace and rhythm. The aim is to go ever faster and become the fastest since the performance of the athlete is compared not only with the present opponent(s), but with all previous ones, too (e.g. track and field). This happens especially in a highly competitive society where winning is not just an issue of pride in one's ability, but carries financial import as well (Hyland, 1990, p. 35 and 41).

When one is striving to win, the quality of experiencing is sidelined. "Faster" is more important than "enjoyed" or "well performed" (e.g. in the spirit of fairplay). In this context, Loland (2000, p. 50) offers a solution to diminish the size of this problem: "In the sprint in athletics, for example, one could simply stop timing and record keeping during the events and instead count and give points for wins and losses in a series of sprints."

Also, it may seem that, during individual performances, especially those of an endurance character, the way of being as falling (Verfallen) is absent - that the striving athlete does not deal so much with entities around him or her, but is especially aware of his or her own body. However, it is important to notice that the attention paid to one's body during the effort to get to the limit does not manifest one's authentic being, but rather an understanding of one's body as a machine, which is to be controlled, given orders to and pushed to its limits (which follows what society expects from the individual human being, i.e. inauthentic being).

One final observation: recorded sport carries within it the possibility of returning the contest to a kind of test (see the beginning of the section called "Event sports"). A standard is set, which challenges (or "tests") the future performances of every other athlete who tries to beat it. As an argument against this characterisation, it might be said that the test is set by the community of practice (such as all pole vaulters), and so it remains a contest. We would maintain, however, that this kind of "competing with the past" carries a quite different sense of the word "social" than that required for the social character of contests. This observation might lead us to a rethinking of the problem of records, and raises a question about how tests are set in any case.

\section{Elements}

The category of mixed sports, which are those sports involving a mixture of time related and event related aspects, consists of sports that have flexible time constraints in which an activity has to be completed. These sports include, for example, events in artistic and rhyth- mic gymnastics, where, for example, the performance on the balance beam or floor exercise must be completed within 1 minute 10 seconds and 1 minute 30 seconds. In such sports, the performance takes characteristics from both, as described in the discussions above. These sports are characteristic of a certain freedom as to finishing a task, as there is a span of time (in this case, 20 seconds) within which the performance needs to be finished. However, the athletes must still be mindful of the duration of their performance, otherwise penalties are given for exceeding the time limit.

This combination may be seen as more athlete friendly, since it gives the athlete the possibility of setting their own optimal individual pace. However, for some athletes, especially the less experienced ones, the limit may still act as a constraint for them, possibly resulting in stress and anxiety in their performance.

\section{Sports encouraging \\ the experiencing of original temporality}

Now we come to those sports in which nothing is measured and time is related only to the start of the performance. When the performance is not determined by a limit, the actual experiencing of the human being can come to the fore and be more fully manifested. In this context we can say that the objective notion of time does not have an over riding importance, and we can get closer to the original temporality of the human being.

We can find this different approach used in those sports where performance is judged on the basis of the aesthetics of performance, or the correct and fluent repetition of given movement forms. This happens, for example, in some aesthetic sports (for the difference between aesthetic and purposive sports, Parry, 1989), such as ice dancing, or also in the martial sports within the performance of kata, where the appropriate rhythm, pace, balanced movement and grace are evaluated.

However, the absence of time limitations is not often a sufficient condition for the realization of original temporality, mainly because of our tendency to be overtaken by our habitual reliance on the objective notion of time. One way is to concentrate on the processes of our experiencing, rather than on what we are experiencing.

There is also one group of sports that may open an approach to the realisation of original temporality - the group of high risk sports (cp. Martínková \& Hsu, 2009; Müller, 2008). The high risk involved in these sports offers the potential to enable the human being to approach his or her original temporality, mainly through their "unhomelikeess" or mysteriousness (Unheimlichkeit) and danger of the situation that the athletes enter, through which they can realize the finitude of their life. These sports often take place outdoors in the countryside (although this is not a necessary condition for them) where the participants are likely to encounter the unexpected. Experiencing an "unhomelike" or scary situation gives 
an opportunity to the human being to experience authenticity (in Heidegger's sense) and to become whole (cp. Breivik, 2010; Jirásek, 2007, p. 162 ff.; Standish, 1998, p. 262).

However, the possibility of experiencing original temporality in high risk sport is not so straightforward. It applies most readily to beginners, since it is only the beginners for whom the whole situation is "unhomelike". Experienced and advanced athletes have usually become so habituated through practice to doing these sports, to dealing with uncomfortable situations, that they do not perceive them as being quite so risky any more (Breivik, 2010). Here, inauthenticity may easily return: the long time practitioners who have become accustomed to the ways and common practices of high risk sport may even come to feel superhuman - invulnerable and unbreakable - and in this way miss the possibility of experiencing themselves as being more fully human.

Nevertheless, when being understood as competitive sports (and not just as free time activities), high risk sports are also regulated by time, so they can also be categorized within the three above mentioned groups (depending on the time limitation in question). The reason for the creation of a fourth group, however, is just because the risk in them, which attracts attention to one's own existence as such, may encourage the possibility of the realization of original temporality. With respect to these sports it may be noted that athletes in high risk sports (and nature sports) often do not value competition very highly, and are skeptical about the competitive versions of their activities (Krein, 2008).

\section{CONCLUSION}

It is possible to say in conclusion that, in Western society in general, as well as in sports, two different concepts of time meet - that is, time understood as being linear, objective, homogeneous and measurable; and the original temporality of the human being. Modern sports are based on the former notion of time, since time conceived as linear, objective and measurable has a constitutive and regulative function within them.

But the notion of time as objective is not the only notion of time there is. With the help of the work of Martin Heidegger the notion of original temporality was introduced and connected to sports. Since the objective concept of time derives from original temporality, sports from all of the above explored groups are always connected to this more fundamental understanding of "time" in any case. However, some sports - we identified mainly high risk sports - are even able to encourage the opening of a possibility for the athlete to experience their original temporality, their own being, as fully human.
In this paper we have tried to describe some of the problems posed by objective time to the way of existence of an athlete, and we hope that it may help athletes and coaches to become aware and mindful of the problematic nature of the role of time in sport, in relationship to an athlete's experiencing.

\section{ACKNOWLEDGEMENT}

The article was written with support from a Research Grant from the Ministry of Education, Youth and Sports MSM 0021620864, Czech Republic.

\section{REFERENCES}

Breivik, G. (2010). Being in the void: A Heideggerian analysis of skydiving. Journal of the Philosophy of Sport, 37(1), 29-46.

D'Agostino, F. (1981). The ethos of games. Journal of the Philosophy of Sport, 8, 7-18.

Guttmann, A. (2004). From ritual to record. New York: Columbia University Press.

Heidegger, M. (1967). Being and time (J. Macquarrie \& E. Robinson, Trans.). Oxford: Basil Blackwell.

Heidegger, M. (1987). Zollikoner Seminare. Frankfurt am Main: Vittorio Klostermann.

Heidegger, M. (1997). Die Grundprobleme der Phänomenologie ( $3^{\text {rd }}$ ed.). Frankfurt am Main: Vittorio Klostermann.

Hempel, H.-P. (2001). Heidegger a zen. Praha: Mladá fronta.

Hogenová, A. (1997). Phenomenology and sport. Acta Universitatis Carolinae Kinanthropologica, 33(2), 47-53.

Hyland, D. A. (1990). Philosophy of Sport. St. Paul, Minnesota: Paragon House.

Jirásek, I. (2007). An experience and Heidegger's analysis of authentic existence. In H. Sheridan, L. A. Howe, \& K. Thompson (Eds.), Sporting Reflections: Some Philosophical Perspectives (pp. 154-170). Oxford: Meyer \& Meyer Sport.

Krein, K (2008). Sport, nature and worldmaking. Sport, Ethics and Philosophy, 2(3), 285-301.

Kretchmar, R. S. (1988). From test to contest: An analysis of two kinds of counterpoint in sport. In W. Morgan \& K. Meier (Eds.), Philosophic inquiry in sport (pp. 223-229). Champaign, IL: Human Kinetics.

Kretchmar, R. S. (2005). Game flaws. Journal of the Philosophy of Sport, 32(1), 36-48.

Loland, S. (2000). The logic of progress and the art of moderation in competitive sports. In T. Tännsjö \& C. Tamburrini (Eds.), Values in Sport (pp. 30-56). London and New York: Routledge. 
Martínková, I. (2007). Time and timelessness in relation to movement practice. In I. Martínková \& M. Peliš (Eds.), Movement - the art of life III. (pp. 43-63). Prague: FTVS UK.

Martínková, I., \& Hsu, L.-H. (2009). Justification of dangerous sports and the question of values. Journal of Humanities and Social Sciences, 5(2), 93-99.

Martínková, I., \& Vágner, M. (2010). Terminologické vymezení bojových aktivit v oblasti kinantropologie. Česká kinantropologie, 14(1), 29-38.

Müller, A. (2008). Risikosport: Suizid oder Lebenskunst? Hamburg: Merus.

Parry, J. (1989). Sport, art and the aesthetic. Sport Science Review, 12, 15-20.

Parry, J. (1998). Violence and aggression in contemporary sport. In M. J. McNamee \& S. J. Parry (Eds.), Ethics and Sport (pp. 205-224). London: Routledge.

Parry, J. (2006). The idea of the record. Sport in History, 26(2), 197-214.

Sokol, J. (2004). Rytmus a čas. Praha: Oikoymenh.

Standish, P. (1998). In the zone: Heidegger and sport. In M. J. McNamee \& S. J. Parry (Eds.), Ethics \& Sport (pp. 256-269). London: Routledge.

\section{DVA ZPŮSOBY POJÍMÁNÍ ČASU VE SPORTU}

(Souhrn anglického textu)

VÝCHODISKA: Text se zabývá jedním ze základních pojmů ve sportu - pojmem času.

CÍLE: Cílem textu je vysvětlit dvě různá pojetí času ve sportu.

METODIKA: Naše metoda je filosofická a zahrnuje pojmovou a fenomenologickou analýzu a aplikaci výsledků do sportovní praxe.

VÝSLEDKY: Nejprve jsou diskutovány dva pojmy času a jejich role ve sportu - pojetí času jakožto lineárního, měřitelného, homogenního a objektivního a čas v podání filosofie existence, zvláště v pojetí Martina Heideggera, který představuje pojem „původní časovost“. Poté jsou sporty rozděleny do čtyřr různých skupin v závislosti na roli, kterou $\mathrm{v}$ nich hraje čas, a jsou rozpracovány jejich základní charakteristiky.

Zatímco v rámci prvních tří skupin se ukazuje důležitost objektivního času, čtvrtá skupina sportů, která zahrnuje vysoce rizikové sporty, poukazuje k možnosti realizace původní časovosti.
ZÁVĚRY: V textu jsou představena dvě pojetí času, která vysvětlují základ sportu a která jsou vztažena k lidskému prožívání $\mathrm{v}$ rámci sportovních aktivit. $\mathrm{V}$ textu je ukázáno, že pojem objektivního času je nutný pro praktikování některých sportů, jiné sporty jej využívají spíše sekundárně, např̀. pro možnost porovnávání vítězů. Původní časovost se jakožto základ lidského prožívání ukazuje ve všech sportech. Zatímco v některých sportech je původní časovost omezována objektivním časem, v jiných (zvláště ve vysoce rizikových sportech) se naopak ukazuje možnost realizace původní časovosti.

Klíčová slova: čas, sport, regulace, prožívání, Heidegger, puvodní časovost.

\section{PhDr. Irena Martínková, Ph.D.}

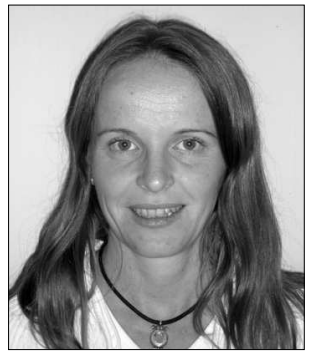

\author{
Charles University \\ Faculty of Physical Education \\ and Sport \\ José Martího 31 \\ 16252 Praha 6 \\ Czech Republic
}

\section{Education and previous work experience}

Assistant lecturer in philosophy of sport at the Faculty of Physical Education and Sport, Charles University in Prague.

\section{First-line publications}

Martínková, I. (2008). The legacy of Kalokagathia. Nikephoros, Zeitschrift für Sport und Kultur im Altertum, 21, 41-49.

Martínková, I., \& Parry, J. (2010). Coaching and the limits of performance enhancement. In A. R. Hardman \& C. R. Jones (Eds.), The Ethics of Sports Coaching (pp. 165-184). London: Routledge.

Martínková, I., \& Parry, J. (2011). Zen and sports: Focusing on the quality of experiencing. In J. Parry, N. Watson, \& M. Nesti (Eds.), Theology, Ethics and Transcendence in Sport (pp. 211-222). New York: Routledge. 